\title{
Influence of Market Value-To- Book Value (MV/BV) and Return on Equity (ROE) Ratios on Investment Decisions of Common Stockholders in Quoted Manufacturing Companies in North-West Nigeria
}

\author{
Dr. Ugbe, A. Sylvester ${ }^{1^{*}} \quad$ Dr. Babat, Auta Lluka ${ }^{2}$ \\ 1.Department of Business Education, Federal College of Education, P.M.B 3045, Kano, Nigeria \\ 2.Department of Business Education, Kaduna State College of Education, Gidan Waya, Nigeria
}

\begin{abstract}
This research work aimed at determining the influence of Market Value-to-Book-Value (MV/BV) and Return on Equity (ROE) ratios on investment decisions of common stockholders in quoted manufacturing companies in North-West Nigeria. Two research questions and two null hypotheses were raised for the study. Descriptive survey design was adopted for the study. The population for the study consisted of 230,898 respondents, made up of 230,638 common stockholders registered with 33 accredited stockbrokerage firms in North-West Nigeria and 260 accountants from 84 quoted manufacturing companies as at $31^{\text {st }}$ December 2017 . The proportionate stratified and purposive sampling techniques were employed to select a sample size of 465 respondents made up of 95 accountants in manufacturing companies and 370 common stockholders registered with accredited stockbrokerage firms in manufacturing companies in North-West Nigeria. The data collected were analyzed using mean to answer the two research questions while t-test analysis was employed in testing the two null hypotheses at 0.05 level of significance. The findings obtained include: market-to-book value ratio is used as a measure of deviations between book and market values of shares and stockholders do not extensively analyse this ratio and Return on Equity ratio is used by stockholders to compare dividend at the end of the financial year for consistency and with returns from other companies in the same industry to a moderate extent. It was, therefore, recommended that Common stockholders should always analyse the firms' Market Value-to-BookValue (MV/BV) and Return on Equity ratios at the end of every financial year to understand it to a great extent as $\mathrm{MV} / \mathrm{BV}$ enables them to know the market value of their shares, determine their stock's performance, while ROE ratio reveals the earning power of a company on stockholders' book value investment and how much returns the stockholders have been receiving for better investment decisions.
\end{abstract}

Keywords: Market value to book value, return on equity, ratios, common stockholders, investment decisions

DOI: $10.7176 /$ RJFA/10-6-05

Publication date:March $31^{\text {st }} 2019$

\section{Introduction}

The uncertainty associated with returns from common stock makes the valuation of common stock more difficult, this is owing to the variability of the returns. The expected returns in form of dividends and capital gain (or losses) are the major variable employed in common stock valuation (Pushpa and Sumangala 2011). According to Roll (2006), common stocks or ordinary shares represent the ultimate ownership position in a company. Common stockholders or shareholders are the residual owners of the company, as they provide permanent capital to the company. By purchasing the common stocks of a company, stockholders are entitled to dividend, which is inconsistent. Stockholders are entitled to dividends after the income claims of other stakeholders have been satisfied. They are the last to have their claims on assets when the company is winding-up.

According to Microsoft ${ }^{\circledR}$ Encarta ${ }^{\circledR}$ Dictionary 2009, a common stockholder is somebody who owns one or more shares of a company's stock. He is also known as an investor in stock. Abraham and David (2011) noted that common stock returns in form of dividends and capital gains are the major determinants of viability of any business organizations. According to the authors, returns on common stock is defined as income received from an investment plus any change in market price, usually expressed as a percentage at the beginning of the investment. The common stock market often takes a long time to reward stockholders with a return on share that corresponds to a company's return on capital. The authors recorded that returns on capital is a measure of a company's profitability, but return on common stock represents a combination of dividends and increases in the share price better known as capital gains. The investors in stock are usually the stockholders who have ownership claim in quoted companies.

Olowe (2008) recorded that a quoted company on the stock exchange, sometimes referred to as a public limited liabilities company is an artificial legal entity incorporated by registration under the law. The author further stated that the relevant law in Nigeria that regulates companies is the Companies and Allied Matters Decree of 1990. The law regards a quoted company as an artificial being who can own assets, enter a contract, it can sue and be sued, have bank account in its own name, incur liabilities to other people and companies, and 
employ other people to work for it.

According to Donaldson (2009) investors always aimed at obtaining satisfactory dividend/capital gain from common stock investment. The investors, therefore, should consider certain aspects of the company's operations when taking investment decision. The author stated that investment decision is the determination of where, when, how, and how much an investor is willing to spend in the pursuit of making a profit.

Financial ratios analysis on common stock investment, according to Altman (2008), helps investors to know the value of a manufacturing company. A manufacturing company, according to Akinlo (1996), is any business that uses components, parts or raw materials to make finished goods. These finished goods can be sold directly to consumers or to other manufacturing businesses that uses them to make different products. The value of a manufacturing company depends on its return which also increases its assets base. Investors are always interested in valuing their present investment and estimating the future growth of their investments in manufacturing companies. This estimate, to a great extent, is usually done through the analysis of financial ratios. Hisham (2008) stated that financial statement analysis by means of financial ratios was introduced in the USA as far back as the late $19^{\text {th }}$ Century. This early interest was directed to the comparison of financial statement ratios for a particular firm over a period of time to monitor the firm's progress. Olowe (2008) stated that investors are interested in financial ratios which indicate how well a company is performing. Two of these financial ratios are considered in this paper, which are, the market Value-to-book value (MV/BV) ratio and return on equity ratio. Haan, Sander and Dirk (2009) stated that a high market Value-to-book value (MV/BV) ratio and return on equity ratio may influence investors positively while a low financial ratio may not interest some stakeholders.

Weston and Brigham (2000) defined Market Value-to-Book Value (MV/BV) Ratio as the measure of the market value of the share to the book value of the share. Market value-to-Book value (MV/BV) ratio is given by dividing the market price per share by the Book value per share. Penman (2010) stated that the higher the ratio, the healthier is the performance of the share in the market place. Investors find the ratio useful because the book value of equity provides a relatively stable and intuitive metric that can be easily compared to the market price. The ratio is an investment valuation ratio used by investors or finance providers to compare market value of a company's shares to its book value (shareholder equity). This ratio, according to Berk, Green and Naik (2012) indicates how much shareholders are contributing/paying for a company's net assets. It is calculated by subtracting company's liabilities from its assets (assets-liabilities). The "price to book" or "price/book value ratio" helps investors to compare the market value, or the price they are normally paying per share, to the traditional measure of the firm's value.

The other financial ratio is Return on Equity ratio (ROE). According to Pandey (2009), Return on Equity ratio reveals the actual return to stockholders after payment of interest to long-term lenders have been deducted. Return on equity (ROE) is given by dividing the Net Profit after tax by stockholders' equity and multiplied by 100. This ratio reveals the earning power of a company on stockholders' book value investment. This ratio indicates how profitable a company is by comparing its net income to its average shareholders' equity. The return on equity ratio (ROE) measures how much the shareholders earned for their investment in the company. The higher the ratio percentage, the more efficient management is in utilizing its equity base and the better return is to investors. The ROE tells common shareholders how effectively their money is being employed. Peer company, industry and overall market comparisons are appropriate; however, it should be recognized that there are variations in ROEs among some types of businesses. In general, financial analysts consider return on equity ratios in the $15-20 \%$ range as representing attractive levels of investment quality.

\section{Statement of the Problem}

Manufacturing companies quoted on the Stock exchange market accumulate or raise their capital from common stock investments by stockholders. The stockholders need to know the value of shares when taking their investment decisions, most especially as manufacturing companies share fluctuate often, causing returns on common stock to be unstable (Garba, 2011). Investors, both the existing and potential investors are therefore, under the problem of taking wise decisions for their investments. Proper analysis of Market Value-to-BookValue (MV/BV) and Return on Equity ratios can to a great extent influence investment decisions of common stockholders. Regrettably, the extent to which investors are aware of the influence of Market Value-to-BookValue (MV/BV) and Return on Equity ratios on investment decision is questionable.

\subsection{Purpose of the Study}

The purpose of this study is to determine the influence of Market Value-to- Book Value (MV/BV) and Return on Equity ratios on investment decisions of common stockholders in manufacturing companies in North-West Nigeria.

\subsubsection{Research Question}

The following research questions guided the study:

1. To what extent does market-to-book ratio influence investment decisions of common stockholders in quoted 
manufacturing companies in North West Nigeria?

2. To what extent does return on equity ratio influence investment decisions of common stockholders in quoted manufacturing companies in North West Nigeria?

\subsubsection{Hypotheses}

The following null hypotheses, formulated at 0.05 level of significance, guided the study.

$\mathrm{Ho}_{1}$ : $\quad$ There is no significant difference in the mean responses of common stockholders and accountants on the influence of market-to-book ratio on investment decisions of common stockholders in quoted manufacturing companies in North-West Nigeria.

$\mathrm{Ho}_{2}$ : There is no significant difference in the mean responses of common stockholders and accountants on the influence of return on equity ratio on investment decisions of common stockholders in quoted manufacturing companies in North-West Nigeria.

\section{Methodology}

The descriptive survey design was adopted for the study. The study was conducted in 84 manufacturing companies in North-West Nigeria. The North-West Nigeria comprises of seven states which are Kaduna, Kano, Jigawa, Katsina, Sokoto, Kebbi and Zamfara States. The population for the study was 230,898 made up of 260 accountants in the 84 manufacturing companies that are listed on the Nigeria Stock Exchange (NSE) and 230,638 common stockholders registered with stockbrokerage firms in North-West Nigeria as at $31^{\text {st }}$ December 2017.

The sample for the study consisted of 465 respondents, made up of 95 Accountants in manufacturing companies and 370 registered common stockholders with accredited stockbrokerage firms in North-West Nigeria. Proportionate stratified sampling technique and purposive random sampling were employed to arrive at the sample size of the study.

The instrument for data collection was structured questionnaire which carried a 5-point scale. The response modes were Very Great Extent (VGE) 5, Great Extent (GE) 4, Moderate Extent (ME) 3, Little Extent (LE) 2 and Very Little Extent (VLE) 1 for each research question. 465 copies of the questionnaire were administered to 95 accountants and 370 common stockholders. The questionnaires were administered to the respondents by the researchers with the help of research assistants. Out of 465 copies of questionnaires administered, 422 were retrieved and used for the study which is made up of 85 Accountants and 337 common stockholders. The data obtained from the field were presented and analysed with descriptive statistics of means and standard deviation to provide answers to the research questions while the corresponding hypotheses were tested with t-test at 0.05 level of significance.

\section{Results}

The results of the study were obtained from the research questions answered. They are presented in Table 1- 4 according to the research questions and hypotheses that guided the study.

\subsection{Research Question 1}

To what extent does Market Value-to-Book value (MV/BV) ratio influence investment decisions of common stockholders in quoted manufacturing companies in North-West Nigeria?

The data for answering the research question are presented in Table 1. 
Table 1

Mean Rating of Respondents on Influence of Market Value-to-Book value (MV/BV) Ratio on Investment Decisions of Common Stockholders in Quoted Manufacturing Companies in North-West Nigeria.

\begin{tabular}{|c|c|c|c|c|}
\hline $\mathrm{S} / \mathrm{No}$ & Items & $\bar{X}$ & $\mathrm{SD}$ & Decision \\
\hline 1 & $\begin{array}{l}\text { A low Market Value-to-Book value (MV/BV) Ratio of a quoted } \\
\text { manufacturing company which indicates under value shares } \\
\text { discourages stockholders. }\end{array}$ & 3.65 & 1.01 & Great Extent \\
\hline 2. & $\begin{array}{l}\text { High } \mathrm{MV} / \mathrm{BV} \text { ratio which indicates high price value of shares in the } \\
\text { market encourages Stockholders. }\end{array}$ & 2.80 & 1.37 & Moderate Extent \\
\hline 3. & $\begin{array}{l}\text { Stockholders take into cognizant the Book-value of their share to } \\
\text { the Market-value. }\end{array}$ & 2.78 & 1.41 & Moderate Extent \\
\hline 4. & $\begin{array}{l}\text { Stockholders use the Market Value-to-Book value (MV/BV) Ratio } \\
\text { to determine how their stock price float in the stock marker. }\end{array}$ & 4.01 & .89 & Great Extent \\
\hline 5. & $\begin{array}{l}\text { Stockholders use Market Value-to-Book value (MV/BV) Ratio as } \\
\text { an indicator of how much their shares will sell in the secondary } \\
\text { market. }\end{array}$ & 4.30 & .84 & Great Extent \\
\hline 6. & $\begin{array}{l}\text { Stockholders believe that a high Book Value-to-Market value ratio } \\
\text { indicates that the value of shares is not growing strong. }\end{array}$ & 2.72 & 1.42 & Moderate Extent \\
\hline 7. & $\begin{array}{l}\text { Investors consider the solvency and survival of the company by } \\
\text { analyzing the Market Value-to-Book value of the company share. }\end{array}$ & 2.90 & 1.41 & Moderate Extent \\
\hline 8. & $\begin{array}{l}\text { Book value greater than market value which shows that financial } \\
\text { market value of the company is less than its stated value or net } \\
\text { worth in the balance sheet discourages investors. }\end{array}$ & 2.68 & 1.30 & Moderate extent \\
\hline 9. & $\begin{array}{l}\text { Stockholders compared the Market value-to-Book value of } \\
\text { companies' shares in the same industry before and during } \\
\text { investment. }\end{array}$ & 4.06 & .92 & Great Extent \\
\hline \multirow[t]{2}{*}{10.} & $\begin{array}{l}\text { Stockholders prefer Book-Value that is equal or higher than } \\
\text { Market-Value of the company share. }\end{array}$ & 2.69 & .90 & Moderate Extent \\
\hline & Cluster Mean & 3.38 & 1.15 & Moderate extent \\
\hline
\end{tabular}

The data in Table 1 revealed that items 2, 3, 6, 7 and 8 have mean scores ranging from 2.32 to 2.90 which were within the boundary limit for Moderate Extent. This implies that those items influence the investment decisions of common stockholders in quoted manufacturing companies in North-West Nigeria to a moderate extent. However, items 1, 4, 5 and 9 had their mean scores range from 3.65 to 4.06 which were within the boundary limit for Great Extent. This implies that those items influence investment decisions of common stockholders in Quoted Manufacturing Companies in North-West Nigeria to a great extent. However, item 10 had a mean score of 2.32 which is within the boundary limit of little extent. This item, therefore, influenced the investment decisions of the common stockholders to a Little Extent. The table further revealed the cluster mean of 3.38 which is within the boundary limit for moderate extent, implying that all the items in the table influence common stockholders to moderate extent.

\subsection{Null Hypothesis 1}

Ho1: There is no significant difference in the mean responses of Common stockholders and Accountants on the influence of Market-to-Book value ratio on investment decisions of common stockholders of quoted manufacturing companies in North-West Nigeria.

Table 2

Summary of t-test Analysis of Stockholders and Accountants on Influence of Book-to-Market ratio on investment decisions of common stockholders in quoted manufacturing companies in North-West Nigeria.

\begin{tabular}{lllllllll}
\hline Group & $\mathrm{N}$ & $\bar{X}$ & SD & DF & t-Cal & t-Crit & P & Decision \\
\hline Common Stockholders & 337 & 3.38 & 1.25 & \multirow{2}{*}{148} & 0.36 & 1.96 & .05 & NS \\
Accountants & 85 & 3.37 & 1.11 & & & & & \\
\hline
\end{tabular}

Table 2 indicated that there is no significant difference in the mean ratings of Stockholders and Accountants on the influence of market-to-book ratio on investment decision of common stockholders of quoted manufacturing companies in North-West Nigeria. The table shows that $\mathrm{t}$-calculated value of 0.36 is less than $\mathrm{t}$ critical table value of 1.96 at 0.05 level of significance and 148 degree of freedom. The null hypothesis is therefore accepted. 
4.3 Question 2: To what extent does Return on Equity ratio influence investment decisions of common stockholders in quoted manufacturing companies in North-West Nigeria?

Table 3

The data for answering the research question are presented in Table 3.

Mean Rating of Respondents on Influence of Return on Equity Ratio on Investment Decisions of Common Stockholders in Quoted Manufacturing Companies in North-West Nigeria.

\begin{tabular}{lllll}
\hline S/No & Items & $\bar{X}$ & SD & Decision \\
\hline 1 & $\begin{array}{l}\text { A high ratio on Return on equity which measures high earnings per } \\
\text { share on investment by the company is considered by Stockholders. }\end{array}$ & 2.20 & 1.07 & Little extent
\end{tabular}

2. Return on equity which indicates how the firm manages its

2.631 .35 Moderate Extent resources that leads to high dividend influences stockholders to maintain or sale their shares in the company.

3. Return on Equity ratio reveals the earning power of a firm and it helps Stockholders to decide on their investment.

4. Management are aware that Return on Equity ratio is a measure of how much investors would react to their investment and investors use it to decide on their investment.

5. Stockholders compared ROE of a manufacturing company with the ratios of other similar companies in the industry to decide either to sale/transfer or retain their shares in manufacturing companies.

6. High return on Equity Ratio would definitely mean the profit will grow strongly in future and this encourages Stockholders.

7. High ROE which shows how well a company uses its fund to generate earning growth influence Stockholders decisions on investment in the company.

8. Stockholders do not consider ROE as high ROE yields no immediate benefits sine stock prices are strongly determine by EPS.

9. Stockholder use ROE of a company to estimate the growth rate of the company.

\section{$2.72 \quad 1.30 \quad$ Moderate extent}

$2.83 \quad 1.40 \quad$ Moderate Extent

\section{$2.92 \quad 1.40 \quad$ Moderate Extent}

\section{$3.87 \quad 1.20 \quad$ Great Extent}

$3.391 .40 \quad$ Moderate Extent

\section{$2.80 \quad 1.33 \quad$ Moderate Extent}

$2.78 \quad 1.35 \quad$ Moderate Extent

10. Stockholders use ROE which represent a company's profitability to estimate how much loan is brought into the company versus

\section{$2.70 \quad 1.31 \quad$ Moderate Extent} Stockholders capital to decide their investment. Cluster Mean

$2.98 \quad 1.20 \quad$ Moderate Extent

The data in Table 3 revealed that items $2,3,4,5,6,7,8,9$ and 10 had mean scores ranging from 2.63 to 3.87 which were within the boundary limit for moderate extent. This implies that return on equity ratio, with regard to those items, influence the investment decisions of common stockholders in quoted manufacturing companies in North-West Nigeria to a moderate extent. However, items 1 had it mean as 2.20. This implies that the item influenced the investment decisions of the common stockholders to a little extent. The cluster mean of 2.98 is within the boundary limit for moderate extent, therefore, stockholders and accountants agreed that the majority of the items on returns on equity ratio influenced the investment decisions of common stockholders in quoted manufacturing companies in North-West Nigeria as to a moderate extent.

\subsection{Null Hypothesis 2}

H2: There is no significant difference in the mean responses of common stockholders and Accountants on the influence of Return on Equity ratio on investment decisions of common stockholders of quoted manufacturing companies in North-West Nigeria.

Table 4

Summary of t-test Analysis of Stockholders and Accountants on influence of Return on Equity Ratio on investment decisions of common stockholders in quoted manufacturing companies in North-West Nigeria.

\begin{tabular}{lllllllll}
\hline Group & $\mathrm{N}$ & $\bar{X}$ & $\mathrm{SD}$ & $\mathrm{DF}$ & t-Cal & t-Crit & $\mathrm{P}$ & Decision \\
\hline Common Stockholders & 337 & 3.38 & 1.25 & & & & & NS \\
Accountants & 85 & 3.37 & 1.11 & & & & & \\
\hline
\end{tabular}

Table 4 showed that there is no significant difference in the mean ratings of Stockholders and Accountants 
on the Influence of Return on Equity Ratio on investment decision of common stockholders of quoted manufacturing companies in North-West Nigeria. The table shown that t-calculated value of 0.59 is less than $\mathrm{t}$ critical table value of 1.96 at 0.05 level of significance and 148 degree of freedom. The null hypothesis is therefore accepted.

\section{Discussion}

The result of this study indicated that most of the market value-to-book value (MV/BV) ratio items studied were to a moderate extent. That is, market-to-book value ratio is used as a measure of deviations between book and market values of shares and stockholders do not extensively analyse this ratio. This supports the view of Garba (2011) who stated that this ratio indicates the value to which the financial markets attached to the management and organization of the company as a going concern. This finding agreed with the view of Ikhsan (2011) who noted that the ratio measure the market value of shares to the book value of the shares. The author further stated that stockholders look forward to firms that increase the market value of their shares as to the book value as inflation do often reduces the value of a firm. With rising inflation, stockholders need to consider the ratio intensively before and after investing in a company, but very few stockholders take time to analyse financial ratios for business decisions.

It was also found that common stockholders to a moderate extent are influenced by return on equity on their investment decisions as stockholders only use the ratio to know returns on equity that is consistently high, compared with the return from other companies in the same industry, or that shows a strong pattern of growth. The studies also indicated that a steady return on equity of more than $15 \%$ is of great interest to the stockholders. The findings of this research corroborate the view of Jauhari (2003) who opined that return on equity ratio is obligations that will be settled at the end of a financial year by companies to retain stockholders. The author further stated that ROE have great effect toward stock returns as every investor surely wants to gain high return from their investment. He further stated that it also helps the company to retain it stockholders and maintain continuous growth. Taken the challenges and inflations facing investment in manufacturing companies in NorthWest Nigeria, manufacturing companies should try to give reasonable dividend as indicated by its profit as return on equity to stockholders to remain in business. Studies by

\section{Conclusions}

Based on the findings of this study on Influence of Market Value-to-Book Value (MV/BV) and Return on Equity ratios on investment decisions of common stockholders in manufacturing companies in North-West Nigeria, the following conclusions were drawn: Common stockholders in quoted manufacturing companies in North-West Nigeria make use of Market Value-to-Book Value (MV/BV) and Return on Equity ratios to analyse the financial strengths and weaknesses of a firm to a moderate extent. The investors do not analysed the two financial ratios extensively before making investment decisions. The two financial ratios studied revealed that investors only make use of financial ratios when they are expecting dividend and when they want to sell their shares.

\section{Recommendations}

Based on the findings and conclusions drawn from the study, the following recommendations were made:

- Common stockholders should always analyse the firms' Market Value-to-Book-Value (MV/BV) and Return on Equity ratios at the end of every financial year. This will enable them to know the market value of their shares, determine their stock's performance, ROE ratio reveals the earning power of a company on stockholders' book value investment and how much returns the stockholders have been receiving for better investment decisions.

- Stockholders who are unable to analyse the firm's Market Value-to-Book-Value (MV/BV) and Return on Equity ratios should employ the services of chartered stockbrokers to analyze and interpret the firm's financial ratios for them, especially when they are making investment decisions.

- Present and intending investors who want to buy share in a company should anlayse the firm's Market Value-to-Book-Value (MV/BV) and Return on Equity ratios or employ the services of chartered stockbroker to assist them in analyzing the firm's financial ratios as it helps to predict the company's future performance, ability to withstand solvency, make comparison among companies, know if the price of share is in line with the earnings, reflect the degree of efficiency exercised by the management, diagnose the company's present and future performances etc.

\section{References}

Abraham, A. and David, I. (2011). The Individual Investor and the Weekend Effect. Journal of Financial and Quantitative Analysis, 15 (2), 126-170.

Akinlo, E. A. (1996). Improving the Performance of the Nigerian Manufacturing Sub-Sector after Adjustment, The Nigerian Journal of Economic and Social Studies, 5 (2), 359-368. 
Altman, E.I. (2008). Financial Ratios, Discriminant Analysis and the Prediction of Corporate Bankruptcy. Journal of Finance, 4(2), 589-609

Berk, J. B. Green, R. C. and Naik, V. (2012). Optimal Investment, Growth Options and Security Returns, Journal of Finance, 15 (3), 1553-1607.

Donaldson, G. (2009). Financial Goals: Management Vs. stockholders. Harvard Business Review, 2 (3), 116-129.

Garba, E. G. (2011). The Benefit and Impliction of Internationalization of Stock Market to Quoted

Companies and the Nigeria Economy. Tambari - Kano Journal of Education, 6 (2), 195-208.

Haan, J. Sander O. and Dirk S. (2009). European Financial Markets and Institutions. Cambridge University Press.

Hisham, F. (2008). The Predictive Power of Financial Ratios in the British Construction Industry. Journal of Business Finance and Accounting 40 (3), 339-352.

Ikhsan P.M. (2011). Analysing Return on Equity. University Sumatra Utara. http://www.sumatra.com. Retrieved on $17^{\text {th }}$ August, 2016.

Jauhari, R. (2003). Analisis Pengaruh Debt to Equity Ratio, Price to Book Value and Return on Equity Ratio on Common Stock. Retrived $18^{\text {th }}$ September, 2018 from http://www.Rev.Integr. Bus. Econ. Res. com/financ.htm.

Microsoft ${ }^{\circledR}$ Encarta ${ }^{\circledR} 2009$. C $1993-2008$ Microsoft Corporation. Retrieved on $28^{\text {th }}$ December, 2016.

Olowe, R.A. (2008). Financial Management Concepts, Analysis and Capital Investment. Brierly Jones Nigeria Limited, Lagos. 89-96.

Pandey I.M. (2009). Financial Management. $9^{\text {th }}$ ed. New Delhi Vikas Publishing House PVT Limited.

Penman, S.H. (2010). The predictive content of earnings, forecasts and dividends. Journal of Finance, 38 (2), 1181-1199.

Pushpa, B. and Sumangala, J.K. (2011). Impact of Earnings per share on Market Value of an Equity Share: An Empirical study in Indian Capital Market. Journal of Finance, Accounting and Management, 3(2), 1-14.

Roll, R. (2006). Industrial Structure and the Comparative Behaviour of International Stock Market Indices. Journal of Finance, American Finance Association, 57 (1), 30-41.

Weston, J.F. and Brigham E.F. (2000). Essential of Managerial Finance, Dryden Press, New York. 125-143. 